Research Article

\title{
Preliminary Synthesis of Calcium Silicates using Oil Palm Leaves and Eggshells
}

\section{Salprima Yudha S1,*, Aswin Falahudin¹, Noor Haida Mohd Kaus², Sirikanjana Thongmee ${ }^{3}$, Saiqa Ikram ${ }^{4}$, Asdim Asdim ${ }^{1}$}

${ }^{1}$ Department of Chemistry, Faculty of Mathematics and Natural Sciences, Universitas Bengkulu, Jalan W.R. Supratman, Kandang Limun, Kota Bengkulu 38371A, Indonesia.

${ }^{2}$ Schools of Chemical Sciences, Universiti Sains Malaysia (USM), 11800 USM, Penang, Malaysia. ${ }^{3}$ Department of Physic, Faculty of Science, Kasetsart University, Bangkok, Thailand.

${ }^{4}$ Department of Chemistry, Faculty of Natural Sciences, Jamia Millia Islamia (Central University), New Delhi, India.

Received: 20th April 2020; Revised: 3rd July 2020; Accepted: 8th July 2020; Available online: 30th July 2020; Published regularly: August 2020

\section{Abstract}

A new synthetic procedure is described for the synthesis of calcium silicate derivatives, using natural resources such as eggshell (ES) for calcium and oil palm leaves (OPL) for silica, which do not require prepurification. The reaction is performed by directly converting two weight ratio of the precursors, ES:3OPL and ES:6OPL, to dried-powder form by heat treatment at $900{ }^{\circ} \mathrm{C}$ for two hours. The results demonstrate that the concentration of the precursors has an effect on the morphology and crystallinity of the calcium silicate derivatives, mainly $\mathrm{Ca}_{2} \mathrm{SiO}_{4}$ and $\mathrm{CaSiO}_{3}$. X-ray diffraction results reveal that the reaction product obtained using a 1:3 ratio is quite pure, and mainly consisted of calcium silicate in the form of $\mathrm{Ca}_{2} \mathrm{SiO}_{4}$. The $\mathrm{CaSiO}_{3}$ was also identified in ES:6OPL, together with a small amount of excess non-reacted crystalline silica. Furthermore, a scanning electron microscopy analysis shows that both reaction products have a coarse surface. Copyright $@ 2020$ BCREC Group. All rights reserved

Keywords: Eggshell; Oil Palm Leaves; Silica; Calcium-silicate

How to Cite: Yudha S, S., Falahudin, A., Kaus, N.H.M., Thongmee, S., Ikram, S., Asdim, A. (2020). Preliminary Synthesis of Calcium Silicates using Oil Palm Leaves and Eggshells. Bulletin of Chemical Reaction Engineering \& Catalysis, 15(2), 561-567 (doi:10.9767/bcrec.15.2.7591.561-567)

Permalink/DOI: https://doi.org/10.9767/bcrec.15.2.7591.561-567

\section{Introduction}

Numerous literatures have paid specific attention to the green synthesis of calcium silicates. For example, wollastonite $\left(\mathrm{CaSiO}_{3}\right)$ was successfully prepared using a hydrothermal method from $\mathrm{CaO}$ obtained from eggshell and $\mathrm{SiO}_{2}$ extracted from diatomite. This method generates a wollastonite mixture of $\beta-\mathrm{CaSiO}_{3}$ and $\alpha-\mathrm{CaSiO}_{3}[1]$. Another approach was devel-

* Corresponding Author.

E-mail: salprima@unib.ac.id (S. Yudha S) oped from natural $\mathrm{CaCO}_{3}$ (eggshell) and commercial $\mathrm{SiO}_{2}$, using ball mill and sonochemical techniques, leading to the exclusive production of $\beta-\mathrm{CaSiO}_{3}$ [2]. Other studies reported $\beta$ wollastonite as the major phase obtained by reacting $\mathrm{CaO}$ from $\mathrm{CaCO}_{3}$ and $\mathrm{SiO}_{2}$ from rice husk ash [3]. This was also achieved using the ashes of rice husk and straw, in combination with $\mathrm{CaO}$, under sintering at $950{ }^{\circ} \mathrm{C}[4-5]$. Meanwhile, solid-state reactions have also proved effective for the preparation of porous wollastonite with high density and mechanical strength, using $\mathrm{CaCO}_{3}$ and $\mathrm{SiO}_{2}$ in the presence of active 
carbon at $1320^{\circ} \mathrm{C}[6]$. Another important derivative is $\mathrm{Ca}_{2} \mathrm{SiO}_{4}$, known as calsil or larnite depending on its crystallite structure, where the basic arrangement of larnite or others $(\alpha, \beta$, and $\gamma$ ) has a heteropolyhedral glaserite framework [7]. Extensive research has been conducted on the synthesis of $\mathrm{Ca}_{2} \mathrm{SiO}_{4}$, including common synthetic and green methods. For instance, $\mathrm{Ca}_{2} \mathrm{SiO}_{4}$ was prepared from the combination of eggshell and tetraethyl orthosilicate (TEOS) as precursors, using a sol-gel combustion treatment [8]. In addition, other reports established the use of natural silica, rice husk, $\mathrm{CaO}$, and eggshell to form calcium silicate derivatives or silica-impregnated $\mathrm{CaO}$. This technique is dependent on the reaction conditions, and the product derived from the use of silicaimpregnated $\mathrm{CaO}$ obtained from rice husk and eggshell is effective as a catalyst in biodiesel preparation [9].

Calcium silicate in the form of $\mathrm{CaSiO}_{3}$ has some industrial applications due to its inherent properties including thermal stability, chemical inertness, and low thermal conductivity and expansion [10]. These materials also serve as important fertilizers that ensure the productivity of some plants, and the silicon component plays a major role in increasing resistance against diseases, abiotic stresses, insect attack, and the effect of climate change [11]. Thus, as a silicate fertilizer, the $\mathrm{CaSiO}_{3}$ can be added to urea as a nitrogen source for paddy growth and to enhance tropical soil productivity, a process that is claimed to reduce $\mathrm{N}_{2} \mathrm{O}$ emission [12]. Furthermore, a commercially available $\mathrm{CaCO}_{3}$ has been used as a precursor of porous $\beta-\mathrm{Ca}_{2} \mathrm{SiO}_{4}$ by its reaction with $\mathrm{SiO}_{2}$ in the presence of tripholyphospate and polyurethane foam, which serve as stabilizer and template, respectively [13].

From an environmental perspective, the use of sustainable natural resources as precursors in the preparation of advanced materials is preferred over materials of synthetic origin. Some recent researches have reported oil palm leaves (OPL) as a potential source for natural $\mathrm{SiO}_{2}$, which is used in several purposes [14-15]. In addition, oil palm ash (OPA), which is obtained from an incinerator at the palm oil mill, form nanostructural materials by high-energy ball milling. The resulting product consists of silica or silicon dioxide $\left(\mathrm{SiO}_{2}\right)$, which is perhaps the most essential substance in OPA [16]. To the best of our knowledge, no studies describing the use of OPL as a source of silica for the synthesis of materials such as wollastonite, larnite, or calsil have been reported. In contrast with reported procedures, the reactions con- ducted in this investigation do not require stabilizers, such as: tricalcium phosphate and the surfactant sodium dodecyl sulfate [13,17]. In the context of sustainable technology, this report describes research results pertaining to the synthesis of silica-based materials using local bioresources and the characterization of the obtained products.

\section{Materials and Methods}

Oil palm leaves (OPL) and eggshell (ES) were washed with aquadest, wiped with tissue, and dried on air. Each material was grounded to powder using a juice mixer and passed through 325 mesh sieves, before repeating the drying process. The synthesis was carried out using two weight ratios of ES and OPL powders, and the corresponding samples were called ES:3OPL and ES:6OPL. For ES:3OPL, 1 $\mathrm{g}$ of ES powder was weighed into a furnace crucible, followed by addition of $3 \mathrm{~g}$ OPL powder. The mixture was homogenized using a glass spatula, and a small amount of demineralized water was added to form a sticky reaction mixture. The crucible was then placed in a furnace and subjected to a heating process. A similar procedure was applied for the sample ES:6OPL, in which $1 \mathrm{~g}$ ES and $6 \mathrm{~g}$ OPL powders were subjected to the heating treatment. The furnace temperature was increased from room temperature to $900{ }^{\circ} \mathrm{C}$ within $4 \mathrm{~h}$, and was kept at that temperature for $2 \mathrm{~h}$. After cooling down the furnace for $12 \mathrm{~h}$, the sample was ready for further analysis.

X-ray diffraction (XRD) analysis was performed to determine the crystallinity phase and the diffraction pattern of the materials, using an X'PERT Powder-PANalytical PW 30/60 instrument. Surface morphology analysis was acquired on a JEOL JSM 6510 LA instrument equipped with an energy dispersive X-ray (EDX) analyzer. The current measurement conditions are: (a) energy range: $0-20 \mathrm{keV}$, (b) Acc. voltage $20.0 \mathrm{kV}$, (c) probe current: 1.00000 $\mathrm{nA}$, (d) real time: $51.28 \mathrm{sec}$, (e) live time: 50.00 sec, (f) dead time: $2 \%$, (g) counting rate: 2850 cps.

\section{Results and Discussion}

A solid-state reaction between OPL and ES powders was performed as shown in Figure 1. The amount of the products obtained using the samples ES:3OPL and ES:6OPL was $0.6301 \mathrm{~g}$ and $1.561 \mathrm{~g}$, respectively. By mixing the powders of yellow-white ES (Figure 1(a)) and green-brown OPL (Figure 1(b)), the mixture shown in Figure 1(c) was obtained. Subsequent 
addition of a small amount of water to ensure homogeneity afforded the material depicted in Figure 1(d). This mixture was heated at $900{ }^{\circ} \mathrm{C}$ for $2 \mathrm{~h}$, leading to the formation of a gray-white solid material (Figure 1(e)), which was characterized as shown in Figure 2.

Since the XRD analysis of ES has been largely investigated [18-20], it was not addressed in the present study. Figure 2(a) shows the amorphous characteristic of the OPL powder. The wide peaks at $21.6^{\circ}$ and $29.9^{\circ}$ and other small peaks can be attributed to the corresponding crystal plane of disordered carbon [21], and are possibly overlapped with those of the silica precursors. After heat treatment at $900{ }^{\circ} \mathrm{C}$ for $2 \mathrm{~h}$, the resulting white-gray solid material was subjected to XRD analysis (Figure 2(b)). A mixture of compounds was identified in the material, being crystalline silica the major component. This result is congruent with previous reports revealing the presence of silica in OPL [14-15]. Figure 3 shows the results of further XRD characterization of the reaction products.

Figure 3(a) shows major diffraction peaks at $2 \theta$ of $32.1^{\circ}, 32.4^{\circ}$, and $41.1^{\circ}$, which can be attributed to $\mathrm{Ca}_{2} \mathrm{SiO}_{4}$ (dicalcium silicate) (JCPDS 00-031-0299), and the XRD pattern was compared with that of other reported approaches [19,22-25]. It should be noted that the present $\mathrm{XRD}$ profile reveals that the reaction products mainly consist of the $\mathrm{Ca}_{2} \mathrm{SiO}_{4}$ phase. This XRD profile was in line with that obtained from the reaction of commercial TEOS as a source of sil-

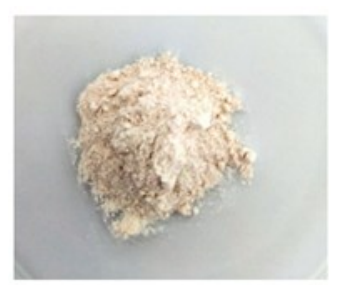

(a)

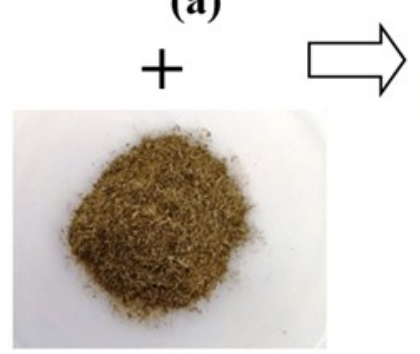

(b)

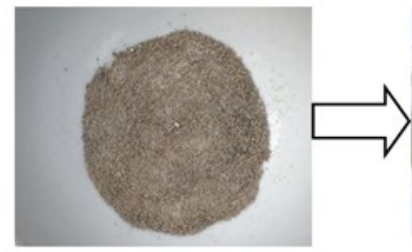

(c)

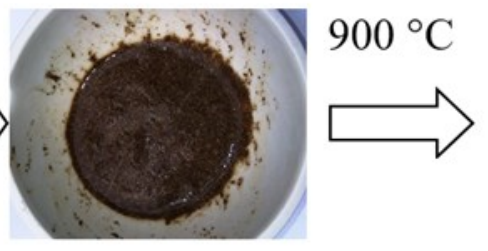

(d)

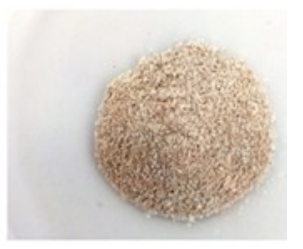

(e)

Figure 1. Representative preparation chart for the reaction between ES and OPL. (a) ES powder, (b) OPL powder, (c) dry mixture of ES and OPL, (d) preheated sticky material, (e) final product.

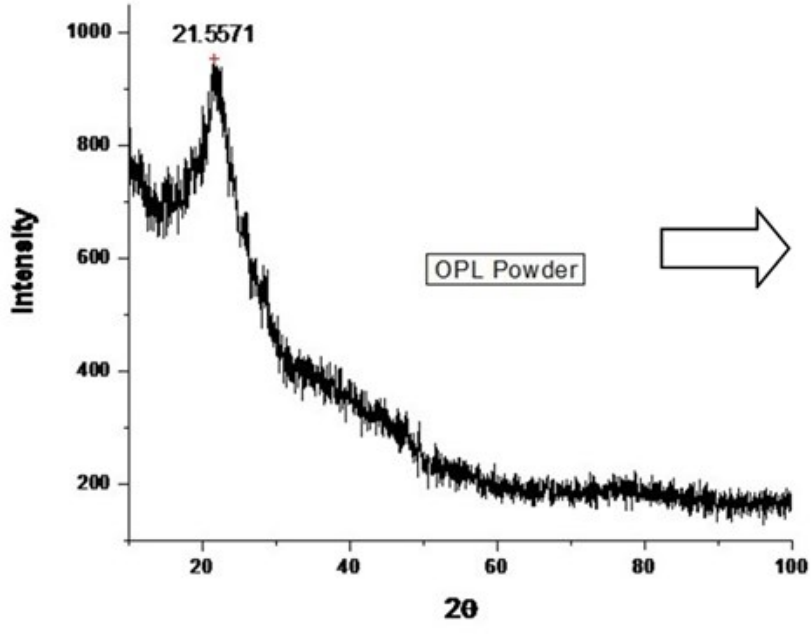

(a)

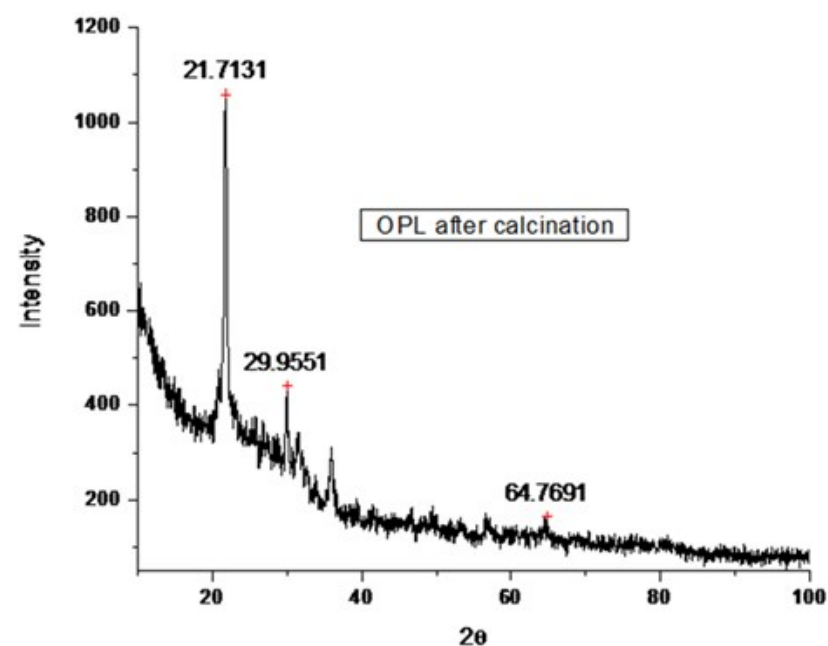

(b)

Figure 2. XRD pattern of (a) OPL powder prior calcination, (b) OPL after calcination at $900{ }^{\circ} \mathrm{C}$ 

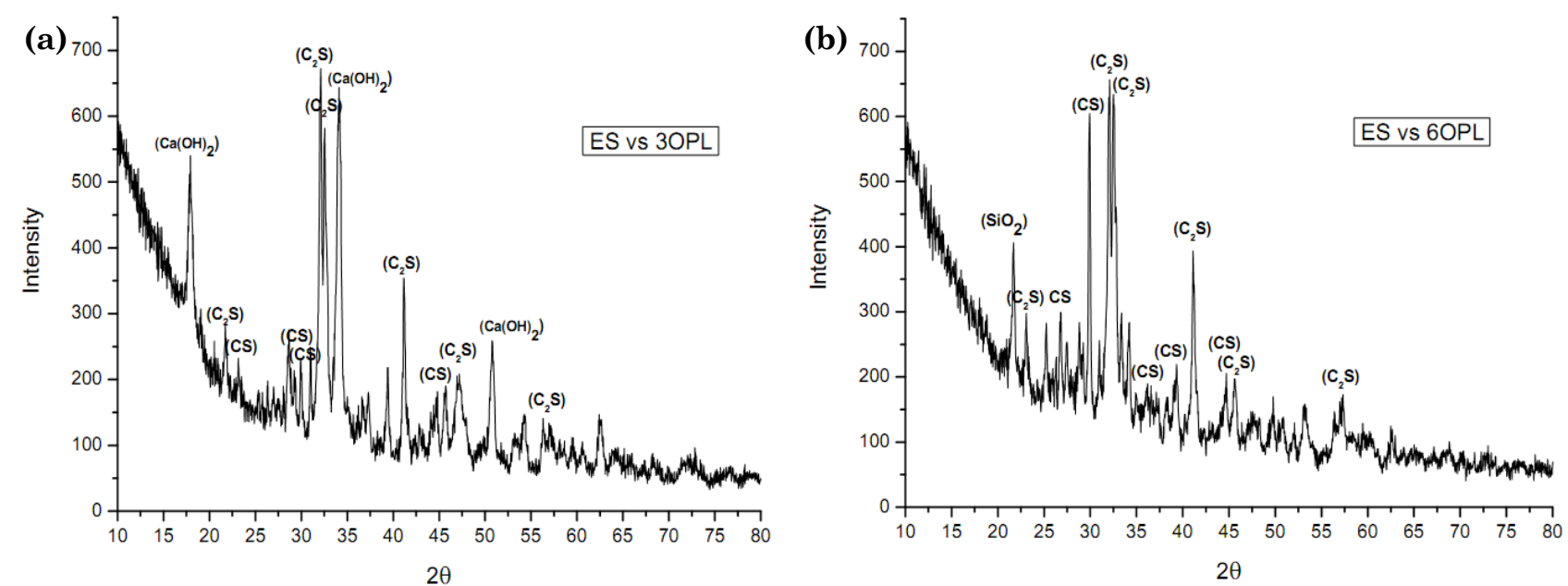

Figure 3. XRD patern of the products of (a) ES:3OPL reaction; (b) ES:6OPL reaction (CS: $\mathrm{CaSiO}_{3}$ and $\left.\mathrm{C}_{2} \mathrm{~S}: \mathrm{Ca}_{2} \mathrm{SiO}_{4}\right)$.
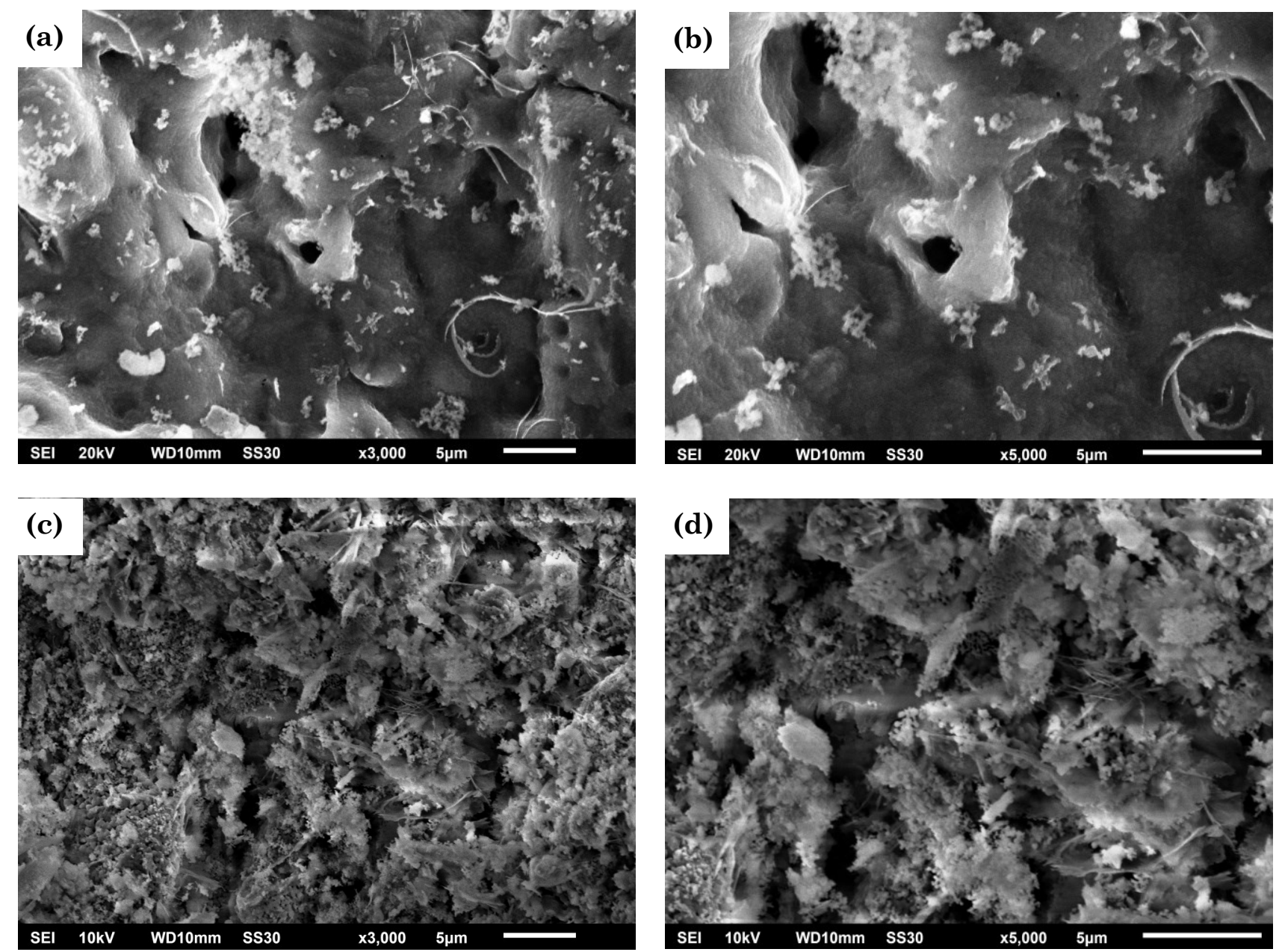

Figure 4. SEM image of (a-b) ES:3OPL and (c-d) ES:6OPL. 
ica and calcium nitrate as $\mathrm{CaO}$ source and other reports $[7,26]$. This suggests that the reactions using the ES-to-OPL ratio of 1:3 tend to produce calcium silicates with $\mathrm{Ca}_{2} \mathrm{SiO}_{4}$ as the major product and $\mathrm{CaSiO}_{3}$ as the minor product. In addition, some impurities were detected, including excess of mineral $\mathrm{CaO}$, which was identified by the presence of peaks at $17.9^{\circ}$, $34.1^{\circ}$, and other overlapped peaks, and was converted to $\mathrm{Ca}(\mathrm{OH})_{2}$ by hydration under air condition. This XRD data was compared with reported results [27-28] and supported by JSPDS 01-073-5492 and ICDD 00-044-1481. Other peaks at $26.8^{\circ}, 29.92^{\circ}, 39.3^{\circ}, 44.7^{\circ}$, and various small peaks were also observed, more clearly in Figure 3(b), indicating the presence of reasonable amounts of $\mathrm{CaSiO}_{3}$. This was compared to previous XRD results on calcium silicates synthesized using pure silica and pure $\mathrm{CaO}$ precursors [29], and referred to JCPDS \#00-043-1460 [30,23]. It was found that higher amounts of $\mathrm{CaSiO}_{3}$ were obtained in the present study, most likely due to the fact that our method preserves the high content of silica precursor in OPL. Despite the higher content of silica and other products such as $\mathrm{CaSiO}_{3}$ in the reaction mixture having a weight ratio of 1:6, similar products were obtained. The XRD patterns displayed in Figure 3a show that the silica was consumed completely, as indicated by the absence of a silica peak as discussed for Figure $1 \mathrm{~b}$, whereas an excess of calcium hydroxide was observed. On the other hand, upon increasing the amount of OPL, a silica peak was observed at $2 \theta=21^{\circ}$, and no $\mathrm{CaO} / \mathrm{Ca}(\mathrm{OH})_{2}$ was found. These evidences indicate that both precursors were converted to the corresponding calcium silicates such as $\mathrm{CaSiO}_{3}$ and $\mathrm{Ca}_{2} \mathrm{SiO}_{4}$.

Despite the lack of experimental evidence, the reaction mechanism for the formation of the calcium silicates derivatives $\mathrm{CaSiO}_{3}$ and

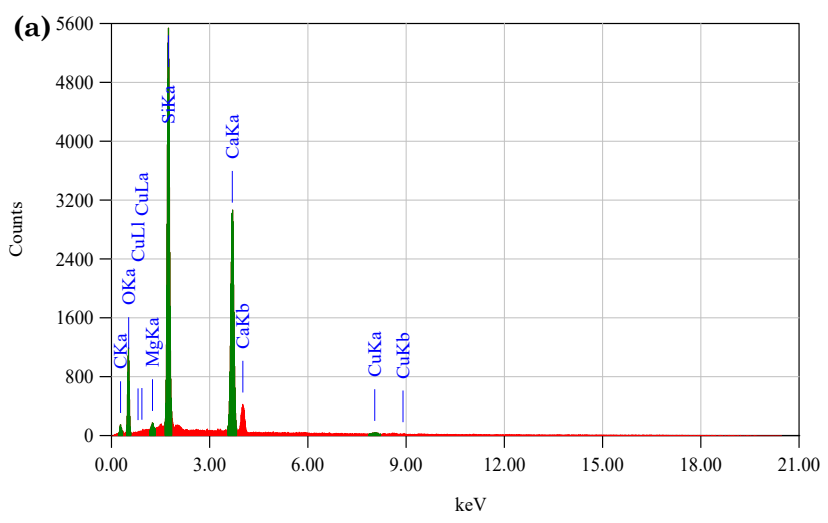

$\mathrm{Ca}_{2} \mathrm{SiO}_{4}$ can be predicted from other studies [24,31]. The interaction between $\mathrm{CaCO}_{3}$ in ES and silicon-based complex compounds in OPL at $900{ }^{\circ} \mathrm{C}$ may proceed as follows:

$$
\mathrm{CaCO}_{3} \text { (egg shell) } \rightarrow \mathrm{CaO}+\mathrm{CO}_{2}
$$

Si-complex (oil palm leaves) $\rightarrow \mathrm{SiO}_{2}$

$\mathrm{CaO}+\mathrm{SiO}_{2} \rightarrow \mathrm{CaSiO}_{3}$

$\mathrm{CaSiO}_{3}+\mathrm{CaO} \rightarrow \mathrm{Ca}_{2} \mathrm{SiO}_{4}$

The calcium silicate product was subjected to scanning electron microscopy (SEM) analysis, and the corresponding results are depicted in Figure 4. Micrometer-sized particles with various shapes are present in both powders, and an irregular surface morphology can be observed. As can be seen in Figure 4(a)-(b), the product of ES:3OPL exhibits an irregular multi-layered surface, whereas more uniform calcium silicate particles are found in Figure 4(c)(d) for the product of ES:6OPL. These morphologies are similar to those obtained using other methods [32-33]. From these SEM results, the surface porosity of the materials cannot be predicted.

Furthermore, an EDX analysis was performed to investigate the major elements present in the products, and the results are shown in Figure 5. Figure 5(a) and 5(b) show the sample composition, which mainly consisted of oxygen, silicon, and calcium, with a minor quantity of copper, magnesium, and zirconium. The EDX data shows that the silicon element comes from OPL, which is in agreement with previous reports [14-15]. The $\mathrm{Ca} / \mathrm{Si}$ ratio could not be determined because the products were not purified. The present method provides new information on the green synthesis of calcium silicates, mainly $\mathrm{Ca}_{2} \mathrm{SiO}_{4}$ and $\mathrm{CaSiO}_{3}$, which has been reported using other silica sources $[3,5,7,34]$.

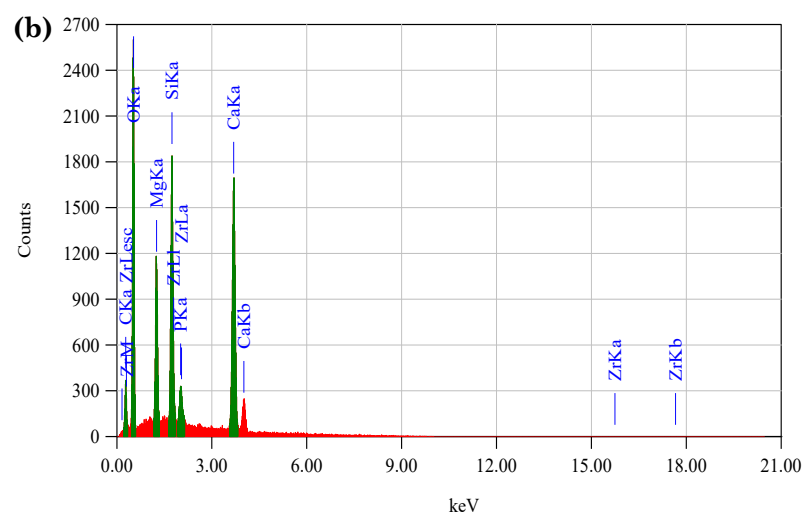

Figure 5. EDX pattern of (a) ES:3OPL and (b) ES:6OPL. 


\section{Conclusions}

Powder materials containing calcium silicate derivatives, mainly $\mathrm{Ca}_{2} \mathrm{SiO}_{4}$ and a small amount of $\mathrm{CaSiO}_{3}$, were successfully synthesized via the solid-state reaction of ES and OPL powders. This approach was executed by simply mixing both materials in the presence of a small amount of water, followed by heating at $900{ }^{\circ} \mathrm{C}$ for $2 \mathrm{~h}$. Further investigation for the application of the reaction products and the use of OPL as a source of silica for preparing other products are on-going in our laboratory.

\section{Acknowledgment}

We are thankful for Lembaga Penelitian dan Pengabdian kepada Masyarakat (LPPM) Universitas Bengkulu for financial support under a scheme "Riset Kolaborasi Internasional" - Fiscal Year 2019 (contract number 2182/UN30.15/LT/2019).

\section{References}

[1] Puntharod, R., Sankram, C., Chantaramee, N., Pookmane, P., Haller, K.J. (2013). Synthesis and characterization of wollastonite from egg shell and diatomite by the hydrothermal method. Journal of Ceramic Processing Research, 14(2), 198-201.

[2] Tiimob, B., Apalangya, V., Samuel, T., Jeelani, S., Rangari, V. (2015). Synthesis, Characterization and In vitro Cytotoxicity Assessment of Eggshell-derived B-CaSiO ${ }_{3}$ Nano Biomaterial. British Journal of Applied Science \& Technology, 8(2), 180-193. DOI: 10.9734/BJAST/2015/16811

[3] Ismail, H., Shamsudin, R., Hamid, M.A.A., Jalar, A. (2013). Synthesis and characterization of nano-wollastonite from rice husk ash and limestone. Materials Science Forum, 756,

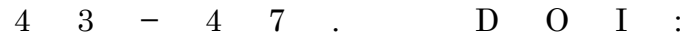
10.4028/www.scientific.net/MSF.756.43

[4] Ismail, H., Shamsudin, R., Hamid, M.A.A. (2016). Effect of autoclaving and sintering on the formation of B-wollastonite. Materials Science and Engineering $C, 58,1077-1081$. DOI: 10.1016/j.msec.2015.09.030

[5] Shamsudin, R., Ismail, H., Hamid, M.A.A., Awang, R. (2016). Characteristics of wollastonite synthesized from rice husk and rice straw. Solid State Science and Tech., 24(1), 61-69.

[6] Hu, Y., Xiao, Z., Wang, H., Ye, C., Wu, Y., Xu, S. (2019). Fabrication and characterization of porous $\mathrm{CaSiO}_{3}$ ceramics. Ceramics International, 45(3), 3710-3714. DOI: 10.1016/j.ceramint.2018.11.034
[7] Yamnova, N.A., Zubkova, N.V., Eremin, N.N., Zadov, A.E., Gazeev, V.M. (2011). Crystal structure of larnite $\beta-\mathrm{Ca}_{2} \mathrm{SiO}_{4}$ and specific features of polymorphic transitions in dicalcium orthosilicate. Crystallography Reports, 56 ( 2 ), $\quad 210-220$. D O I : $10.1134 / \mathrm{S} 1063774511020209$

[8] Choudhary, R., Venkatraman, S.K., Rana, A., Swamiappan, S. (2016). In vitro bioactivity studies of larnite and larnite/chitin composites prepared from bio-waste for biomedical applications. Bulletin of Material Science, 39(5), 1213-1221. DOI: 10.1007/s12034-0161245-4

[9] Lani, N.S., Ngadi, N., Yahya, N.Y., Rahman, R.A. (2016). Synthesis, characterization and performance of silica impregnated calcium oxide as heterogeneous catalyst in biodiesel production. Journal of Cleaner Production, 146, 116-124. DOI: 10.1016/j.jclepro.2016.06.058

[10] Chen, C.-C., Ho, C.-C., Lin, S.-Y., Ding, S.-J. (2014). Green synthesis of calcium silicate bioceramic powders. Ceramics International, 41 (4), $5445-5453$. D O I : 10.1016/j.ceramint.2014.12.112

[11] Meena, V.D., Dotaniya, M.L., Coumar, V., Rajendiran, S., Ajay, Kundu, S., Rao, A.S. (2014). A Case for Silicon Fertilization to Improve Crop Yields in Tropical Soils. Proc. Natl. Acad. Sci., India, Sect. B Biol. Sci., 84(3), 505-518. DOI: 10.1007/s40011-0130270-y

[12] Ku, H.-H., Hayashi. K., Agbisit, R., VillegasPangga, G. (2017). Effects of calcium silicate on nutrient use of lowland rice and greenhouse gas emission from paddy soil in the philippines under alternating wetting and drying. Pedosphere, 30(4), 535-543. DOI: 10.1016/S1002-0160(17)60401-6

[13] Dai, Y., Liu, H., Liu, B., Wang, Z., Li, Y., Zhou, G. (2015). Porous b-Ca $\mathrm{SiO}_{4}$ ceramic scaffolds for bone tissue engineering: in vitro and in vivo characterization. Ceramics International, 41(4), 5894-5902. DOI: 10.1016/j.ceramint.2015.01.021

[14] Onoja E., Attan, N., Chandren, S., Razak, F.I.A., Keyon, A.S.A., Mahat, N.A., Wahab, R.A. (2017). Insights into the physicochemical properties of the Malaysian oil palm leaves as an alternative source of industrial materials and bioenergy, Malaysian Journal of Fundamental and Applied Sciences, 13(4), 623-631.

[15] Onoja, E., Chandren, S., Ilyana, F., Razak, A., Wahab, R.A. (2018). Extraction of nanosilica from oil palm leaves and its application as support for lipase immobilization. Journal of Biotechnology, 283(10), 81-96. DOI: 10.1016/j.jbiotec.2018.07.036 
[16] Khalil, H.P.S.A., Fizree, H.M., Jawaid, M., Alattas, O.S. (2011). Preparation and characterization of nanostructured materials from oil palm ash: a bioagricultural waste from oil palm mill. BioResources, 6(4), 4537-4546.

[17] Mehrali, M., Shirazi, S.F.S., Baradaran, S., Mehrali, M., Metselaar, H.S.C., Kadri, N.A.B, Osman, N.A.A. (2014). Facile synthesis of calcium silicate hydrate using sodium dodecyl sulfate as a surfactant assisted by ultrasonic irradiation. Ultrasonics Sonochemistry, 21, $\begin{array}{llllllllllll}7 & 3 & 5 & - & 7 & 4 & 2 & & & \text { D } & \text { O } & \text { I }\end{array}$ : 10.1016/j.ultsonch.2013.08.012

[18] Ok, Y.S., Lee, S.S., Jeon, W.-T., Oh, S.-E., Usman, A.R.A., Moon, D.H. (2011). Application of eggshell waste for the immobilization of cadmium and lead in a contaminated soil. nviron Geochem Health, 33, 31-39. DOI: 10.1007/s10653-010-9362-2

[19] Choudhary, R., Koppala, S., Swamiappan, S. (2015). Bioactivity studies of calcium magnesium silicate prepared from eggshell waste by sol-gel combustion synthesis. Journal of Asian Ceramic Societies, 3(2), 173-177. DOI: $10.1016 /$ j.jascer.2015.01.002

[20] Zaman, T., Mostari, M.S., Al Mahmood, M.A., Rahman, M.S. (2018). Evolution and characterization of eggshell as a potential candidate of raw material. Cerâmica, 64, 236-241. DOI: 10.1590/0366-69132018643702349

[21] Yu, K., Wang J., Song, K., Wang, X., Liang, C., Dou, Y. (2019). Hydrothermal synthesis of cellulose-derived carbon nanospheres from corn straw as anode materials for lithium ion batteries. Nanomaterials, 9(1), 93 (13 pages). DOI: 10.3390/nano9010093

[22] Arslan, Y., Kendüzler, E., Adigüzel, V.T., Tomul, F. (2019). The Effect of Synthesis Conditions on Calcium Silicate Bioceramic Materials. Journal of Natural and Applied Sciences, 23 ( 2 ), $727-737$. D O I : 10.19113/sdufenbed.527602

[23] Lakshmi, R., Velmurugan, V., Sasikumar, S. (2013). Preparation and phase evolution of wollastonite by sol-gel combustion method using sucrose as the fuel. Combustion Science and Technology, 185, 1777-1785. DOI: 10.1080/00102202.2013.835308

[24] Lugo, G.J., Mazón, P., De Aza, P.N. (2015). Phase transitions in single phase $\mathrm{Si}-\mathrm{Ca}-\mathrm{P}$ based ceramic under thermal treatment. Journal of the European Ceramic Society, 35, $\begin{array}{lllllllllllll}3 & 6 & 9 & 3 & - & 3 & 7 & 0 & 0 & \text {. } & \text { D O I : }\end{array}$ 10.1016/j.jeurceramsoc.2015.04.036

[25] Choudhary, R., Koppala, S., Srivastava, A., Sasikumar, S. (2015). In-vitro bioactivity of nanocrystalline and bulk larnite/chitosan composites: comparative study. Journal of Sol-Gel Science Technology, 74, 631-640. DOI: 10.1007/s10971-015-3642-3.
[26] Booncharoen, W., Jaroenworaluck, A., Stevens, R. (2011). A synthesis route to nanoparticle dicalcium silicate for biomaterials research. Journal of Biomedical Materials Research B: Applied Biomaterials, 99B(2), 230-238. DOI: 10.1002/jbm.b.31890

[27] Kontoleontos, F., Tsakiridis, P., Marinos, A., Katsiotis, N., Kaloidas, V., Katsioti, M. (2013). Dry-grinded Ultrafine Cements Hydration. Physicochemical and Microstructural Characterization. Materials Research, 16(2), 404-416. DOI: 10.1590/S151614392013005000014

[28] Khachani, M., El Hamidi, A., Halim, M., Arsalane, S. (2014). Non-isothermal kinetic and thermodynamic studies of the dehydroxylation process of synthetic calcium hydroxide $\mathrm{Ca}(\mathrm{OH})_{2}$. J. Mater. Environ. Sci., 5(2), 615-624.

[29] Kale, K.B., Raskar, R.Y., Rane, V.H., Gaikwad, A.G. (2012). Preparation and characterization of calcium silicate for $\mathrm{CO}_{2}$ sorption. Adsorption Science \& Technology, 30(10), 817-830. DOI: $10.1260 \% 2 \mathrm{~F} 0263$ 6174.30.10.817

[30] Adams, L.A., Essien, E.R., Kaufmann, E.E. (2018). A new route to sol-gel crystalline wollastonite bioceramic, Journal of Asian Ceramic Societies, 6(2), 132-138. DOI: 10.1080/21870764.2018.1480685

[31] Zhao, C., Wang, G. (2015). The Melting Reaction Mechanism of $\mathrm{NaOH}$ in Decomposing $\mathrm{Ca}_{2} \mathrm{SiO}_{4}$. Mineral Processing and Extractive Metallurgy Review: An International Journal, $36(6), \quad 385-390$. D O I : 10.1080/08827508.2015.1019067

[32] Washizawa, N., Narusawa, H., Tamaki, Y., Miyazaki, T. (2012). Production of a calcium silicate cements material from alginate impression material. Dental Materials Journal, 31(4), 629-634. DOI: 10.4012/dmj.2012-027

[33] Gou, Z., Chang, J., Zhai, W. (2005). Preparation and characterization of novel bioactive dicalcium silicate ceramics. Journal of the European Ceramic Society, 25, 1507-1514. DOI: 10.1016/j.jeurceramsoc.2004.05.029

[34] Vichaphund, S., Kitiwan, M., Atong, D., Thavorniti, P. (2011). Microwave synthesis of wollastonite powder from eggshells, Journal of the European Ceramic Society, 31, 24352440. DOI: $10.1016 / \mathrm{j} . j$ eurceramsoc. 2011.02.026 